\title{
Mapping Multicultural Education
}

\section{Citation}

Levinson, Meira. 2010. Mapping Multicultural Education. In The Oxford Handbook of Philosophy of Education, ed. Harvey Siegel, 428-450. Oxford; New York: Oxford University Press.

\section{Permanent link}

http://nrs.harvard.edu/urn-3:HUL.InstRepos:10860786

\section{Terms of Use}

This article was downloaded from Harvard University's DASH repository, and is made available under the terms and conditions applicable to Other Posted Material, as set forth at http:// nrs.harvard.edu/urn-3:HUL.InstRepos:dash.current.terms-of-use\#LAA

\section{Share Your Story}

The Harvard community has made this article openly available.

Please share how this access benefits you. Submit a story.

Accessibility 


\title{
Mapping Multicultural Education
}

\author{
Meira Levinson \\ Oxford Handbook of Philosophy of Education, ed. by Harvey Siegel..
}

Multicultural education is a conceptual mess. It stands in for people’s political aspirations, but has no independent meaning or value-despite its advocates’ pretences (and beliefs) to the contrary. This is not to say that the various meanings and values attached to multicultural education by its various proponents are themselves worthless; to the contrary, they are often both plausible and compelling. But these meanings and values neither derive from nor are clarified by the concept of “multicultural education” itself. Furthermore, “multicultural education” is saddled with so many different conceptions that it is inevitably self-contradictory both in theory and in practice; even in its most well-intentioned, assiduous, and effective implementation, it cannot simultaneously achieve all of the goals it is called upon to serve. Thus, I shall argue in this chapter, "multicultural education” has no independent identity or value beyond the various goals, practices, or content to which others attach it, and to know that an education is called "multicultural” is to know little if anything about its form, content, or aims.

This is, admittedly, a curmudgeonly way to begin an essay about multicultural education. Why write about something that I claim is intrinsically muddled and even self-contradictory? There are two important reasons to do so. First, “multicultural education” is used so frequently, and often with such potent political consequences, that it is important to come to grips with its multiple possible meanings, to recognize its various uses by different advocates and organizations, and to make sense of the ways these meanings and uses may reinforce, undermine, and/or simply bypass each other. If we have a conceptual map of what "multicultural education" 
is used to mean, then we will be far better equipped to comprehend and evaluate claims made about, against, and on behalf of multicultural education in philosophical, educational, and policy literature. Second, as I noted above, many of the aims and practices attached to "multicultural education" often are quite valuable and hence worth promoting — but in the confusion of so many meanings attached to multicultural education, their value may get lost in the mix. Too often, for example, one politically unpopular or conceptually incoherent version of multiculturalism is used as an excuse to reject other approaches to multicultural education out of hand, even though the latter are in fact totally separate from and even potentially in conflict with the former. Furthermore, at least as problematically, achievement of one version of multicultural education is frequently cited as an excuse not to pursue other, often more challenging and transformative, goals and practices—even though the latter may be more important and desirable. In sum, therefore, it is crucial that we "map" multicultural education as a set of concepts, practices, and goals, even if the map proves to include somewhat contradictory directions and in fact requires outside intervention to clarify one's direction in the first place.

Section I begins to construct this map by surveying the different uses and meanings of "multicultural education” as articulated by three groups: political and educational philosophers, educational theorists (or as I sometimes call them, educational multiculturalists), and educational practitioners. Section II examines some of the inconsistencies and potentially serious contradictions among the aims, calling into question the conceptual coherence of "multicultural education.” Section III then highlights some potential tensions among the aims, practices, and content of multicultural education. I show that promotion of toleration and mutual respect, for example, may actually be better achieved by not teaching students about “others” than by teaching students about other cultures’ very different ways of life. Relatedly, certain central 
multicultural goals may be more easily achieved in segregated rather than integrated settingsexactly the opposite of what almost any self-respecting advocate of multicultural education would favor. ${ }^{1}$ I conclude with a brief reflection on multicultural education's potential practical importance despite its conceptual incoherence.

\section{Mapping the Aims of Multicultural Education}

One of the reasons that "multicultural education" has such a multiplicity of meanings is that it has been embraced and developed by a number of different groups of thinkers who tend not to read each other's work (or seemingly even know of each others' existence). In this section, I will try to map out the work of three such groups who are particularly relevant to readers of a handbook on philosophy of education: political and educational philosophers, multicultural educational theorists, and educational policymakers and practitioners. Let us start with the philosophers.

Multicultural education tends to be invoked in the political and educational philosophy literature for three purposes. First, multicultural education is used to respond to claims by minority groups within a community or nation for group rights or accommodations. Will Kymlicka notably defends this notion in Multicultural Citizenship, arguing, "[W]e should aim at ensuring that all national groups have the opportunity to maintain themselves as a distinct culture, if they so choose. This ensures that the good of cultural membership is equally protected for the members of all national groups” (Kymlicka 1995: 113; see also Young 1990; Tamir 2002). These minority group preservation programs may be voluntary, as when Hispanic families are given the choice about whether to enroll their children in bilingual or English immersion programs; or they may be involuntary, as when the National Curriculum in Wales requires 
instruction in Welsh language, literature, and culture; or when all non-Anglophone (and all immigrant, whether Anglophone or not) children in Quebec are required to attend Francophone schools. They are unusual in American public schools, although they do occasionally arise: "Communication in Native languages takes place primarily to share expression of ideas, thoughts, and feelings to preserve Native cultural ideology” (New York State 1996: Standard 1, Checkpoint A, Native American Languages). More frequently we see them in the form of accommodations of minority religious groups' requests to be exempted from certain curricula or classes, as when conservative Christian students are exempted from biology or gym class (see, e.g., Moody v. Cronin) — or most drastically, in the case of Amish students' exemption from any formal schooling after eighth grade on the grounds that continued school attendance would fundamentally threaten the continuation of the Amish way of life (Wisconsin v. Yoder). Interestingly, such educational exemptions are rarely referred to as multicultural education (a fact which we will return to below), but they are logical extensions of the explicitly multicultural goal of preserving minority group cultures.

Second, multicultural education is invoked by liberal political theorists and philosophers of education as a means of promoting children's development of autonomy. As Rob Reich argues, "Multicultural education fosters minimalist autonomy by (1) creating and enhancing the possibility of critical and independent reflection, and (2) making vivid to the student a diversity of cultural practices and values, which themselves may come to represent real and meaningful options that the student could choose and seek to adopt or pursue” (2002: 132). Thus, multicultural education helps students develop autonomy in two ways: it gives them a set of new options for how to lead their lives by expanding their "experiential horizons" (2002: 184) and it spurs them into reflecting critically on their current lives by placing their received "practices and 
values” in sharp relief against alternative or opposed ones. It is worth noting that these aims aren't propounded solely by philosophers, although they articulate them most clearly. Consider Montana’s English curriculum: “Literature is a primary vehicle to widen and extend our experiences, to make us more aware of other individuals, issues, cultures and viewpoints and, thus, ourselves, our own cultures and our own attitudes. Literature moves us out of our personal spheres and extends our understanding as we change” (Montana Office of Public Instruction 1999). Furthermore, we should note that this approach to multicultural education may provide benefits beyond students’ development of autonomy per se. Understood this way, multicultural education may also be credited with strengthening students' understanding of the world and access to meaningful ideas, practices, and ways of life by simply expanding the realm of human achievements to which they are exposed, whether or not they become more autonomous as a result (Appiah 1996). Thus, exposure to a variety of valuable achievements and ways of life may be justified on autonomy grounds or simply as a good in itself.

Finally, multicultural education is invoked by philosophers as a means to promote the civic good. Multicultural education does this in four related ways.

1. It is thought that as students learn about other cultures, they will come to tolerate them, and hence also tolerate people who live within that culture (see, e.g., Gutmann 1996). This is probably the most familiar and universally embraced purpose of multicultural education—often to the neglect of all other purposes, much to some multiculturalists’ regret. New South Wales’ “Making Multicultural Australia” Web site explains, for example, that its purpose is to help teachers “promote cultural diversity and tolerance”; although many other purposes are also articulated along the way (such as providing "information on the contributions that different 
cultural groups have made to the development of Australian society”), they generally are tied back to the goals of promoting "tolerance" and "community harmony" (NSW Department of Education and Training and Office of the Board of Studies NSW 2007).

2. It is hoped that with tolerance will also come respect. Often, respect is thought to be promoted by teaching students about the achievements of other cultures, including their contributions to the nation. This explains California's mandate that first graders will "[u]nderstand the ways in which American Indians and immigrants have helped define Californian and American culture" (California Department of Education 2000: 1.5.2), and the English National Curriculum's “Respect for All” Web site’s reminder, “Respect for diversity can be promoted in all subjects by drawing examples from different countries, cultures and communities and encouraging pupils to focus on the way human diversity enriches our lives" (Qualifications and Curriculum Authority 2007b). By helping students develop respect for other cultures or ways of life, and therefore for their fellow citizens, multicultural education promotes the civic good by increasing civic harmony.

3. Liberal philosophers argue that in coming to respect different groups within the polity, individuals also become more open to considering different viewpoints within public deliberation and debate. Stephen Macedo articulates this idea as follows: "All children should be made aware of the ethnic, racial, and religious diversity that constitutes our society so that they can think as citizens and so that they will not live in a mental straitjacket at odds with freedom” (Macedo 2000: 240). New York State seems to be gesturing toward this aim in the following English Language-Arts standard: students are expected to "understand that within any group there are many different points of view depending on the particular interests and values of the individual, and recognize interests and values of the individual, and recognize those differences 
in perspective in texts and presentations" (New York State 2003: Standard 3.1, Intermediate, 58). This increase in open-mindedness promotes civic cooperation.

4. Finally, political liberals emphasize that because multicultural education has taught them to be aware of people's differences, citizens become more aware of what constitutes a "public reason" (Rawls 1993) —meaning a reason that lots of people will recognize as legitimate, regardless of their religious or cultural differences, as opposed to a sectarian claim within public discourse. Because they are respectful of these differences, they become more willing to rely on public reasons and to insist that others do, likewise. This awareness of and commitment to public reasons promotes civic reasonableness and civic equality. Thus, Macedo ultimately argues,

A liberal civic education will insist that children learn that it is possible for fellow citizens who affirm the political supremacy of liberal values to disagree deeply about other matters: not only cultural tastes, but also deep religious convictions. A liberal pluralistic multiculturalism will insist on the good of political respect for many different religions and cultures, while acknowledging the political authority of a shared point of view. Multiculturalism properly understood is an important part of a liberal civic education. (2000: 260)

Educational theorists tend to have a significantly different agenda from that of political theorists when they discuss multicultural education. Most notably, educational multiculturalists view the philosophers' approach to multicultural education as being overly, even exclusively, individually oriented and curriculum-based. Multicultural education, they argue, is not simply about tinkering with the content of the curriculum—adding topics here to encourage toleration of others, or developing a new course there so as to promote autonomous thinking and perspective taking. As Sonia Nieto comments, "Many people assume that multicultural education is little more than isolated lessons in sensitivity training or prejudice reduction, or separate units about cultural artifacts or ethnic holidays.... If conceptualized in this limited way, multicultural education will have little influence on student learning” (Nieto 2001: 383). James Banks agrees, 
deriding both what he calls the "contributions approach" and the "additive approach.” "The contributions approach often results in the trivialization of ethnic culture, the study of their strange and exotic characteristics, and the reinforcement of stereotypes and misconceptions” (Banks 2001a: 231). The additive approach, too, "usually results in the viewing of ethnic content from the perspectives of mainstream historians, writers, artists, and scientists because it does not involve a restructuring of the curriculum. The events, concepts, issues, and problems selected for study are selected using mainstream-centric and Eurocentric criteria and perspectives” ( 2001b: 232).

Rather, these educational theorists argue, multicultural education should be transformative, restructuring and regrounding the curriculum, and more important, reorienting the school as a whole to instantiating and promoting social justice and real equality. Banks, who is the grandfather of the multicultural education movement in the United States, explains,

To implement multicultural education in a school, we must reform its power relationships, the verbal interaction between teachers and students, the culture of the school, the curriculum, extracurricular activities, attitudes toward minority languages, the testing program, and grouping practices. The institutional norms, social structures, causebelief statements, values, and goals of the school must be transformed and reconstructed. (Banks 2001b: 22)

Thus, although the goal of using multicultural education to teach antiracism, which all educational theorists embrace and which Sonia Nieto describes as being "at the very core of a multicultural perspective,"2 may seem related to political theorists’ notion of using multicultural education to teach mutual toleration and respect, Nieto argues against mere curricular inclusiveness: "Being antiracist and antidiscriminatory means paying attention to all areas in which some students are favored over others: the curriculum, choice of materials, sorting policies, and teachers' interactions and relationships with students and their families” ( 2000: 305-306)..$^{3}$ 
The result of this transformation not only of the curriculum but also of the formal and informal structures and orientation of the school is generally intended to be twofold. First, educational multicultural theorists hope to promote societal transformation and reconstruction, specifically with regard to eliminating racism, prejudice, and discrimination. Banks’s highest form of multicultural education, for example, is the "Social Action Approach," for which he sets this goal: “A major goal of the social action approach is to help students acquire the knowledge, values, and skills they need to participate in social change so that victimized and excluded ethnic and racial groups can become full participants in U.S. society and so the nation will move closer to attaining its democratic ideals.... In this approach, teachers are agents of social change who promote democratic values and the empowerment of students” (Banks 2001a: 236). Likewise, noted multicultural theorists Carl A. Grant and Christine E. Sleeter distinguish five approaches to multicultural education, labeling the most desirable one, "Education That Is Multicultural and Social Reconstructionist” (Grant and Sleeter 1999). This approach, they explain, "deals more directly than the other approaches have with oppression and social structural inequality based on race, social class, gender, and disability. Its purpose is to prepare future citizens to reconstruct society so that it better serves the interests of all groups of people, especially those who are of color, poor, female, and/or with disabilities” (Grant and Sleeter 2001: 68-69). ${ }^{4}$

The other aim that educational theorists of multiculturalism highlight is that of promoting equal educational opportunity for all students. "Multicultural education is an idea, an educational reform movement, and a process whose major goal is to change the structure of educational institutions so that male and female students, exceptional students, and students who are members of diverse racial, ethnic, language, and cultural groups will have an equal chance to achieve academically in school” (Banks 2001c: 1; see also Gay 2001; Banks and Banks 2004). 
For this purpose, the point of changing the curriculum, pedagogy, and school structure in response to nonmainstream groups' beliefs, norms, and practices is not so that others can learn about these groups, but so that members of the groups themselves will be more likely to achieve, since they presumably will respond more favorably to schools that are "culturally congruent" (Gay 2000) or “culturally relevant” (Ladson-Billings 1994) rather than culturally alien. In this respect, multicultural education is aligned with the groups being taught, as opposed to being about them. "Pedagogical equality that reflects culturally sensitive instructional strategies is a precondition for and a means of achieving maximal academic outcomes for culturally diverse students” (Gay 1995: 28).

In certain respects, therefore, the educational multiculturalists and the philosophers are aligned. Both groups embrace one aim of multicultural education as strengthening historically marginalized and/or minority communities, although educational multiculturalists tend to be more concerned with cultural empowerment (e.g., Ladson-Billings 1994), while philosophers focus more on how multicultural education may promote cultural preservation. ${ }^{5}$ Furthermore, many educational theorists embrace notions of civic solidarity and the value of gaining multiple perspectives:

Multicultural movements have defined the main purpose of curriculum as social improvement. . . . for equality and justice, and a belief that education should fuel democratic actions. Broadly speaking, multicultural movements challenge the United States to live up to its ideals of justice and equality, believing that this country has the potential to work much better for everyone. As tomorrow's citizens, children in schools should learn academic tools and disciplinary knowledge resources from vantage points of multiple communities. Further, young people should develop some sense of solidarity across differences that enables working toward closing the gap between the nation's ideals and its realities. (Sleeter 2005: 15)

As this quotation demonstrates, however, these values are embedded within a thoroughgoing egalitarian commitment to social justice: students should learn to understand others' perspectives 
and to respect others not merely so as to treat each other as civic and political equals, which is the goal articulated by the political philosophers cited above, but also so as to be motivated to act on others' behalf_-actively to pursue social and political equality. This latter aim is more politically partisan, insofar as it privileges the goal of civic equality over other equally democratic goals such as liberty. Hence, the apparent alignment among the various goals should not be mistaken to imply total consistency among them.

Finally, there are three aims for multicultural education that tend to be promoted mostly by educational practitioners (teachers, administrators, and curriculum developers) rather than theorists, as well as one aim that is articulated by all three groups (political and educational philosophers, educational theorists, and educational policymakers and practitioners) alike. This latter aim is that of righting the historical record-education that incorporates multicultural perspectives, it is generally agreed by now, is more accurate than education that presents only one perspective, especially but not only when the single perspective is that of the dominant group. Thus, Gary Nash, a historian who has written a number of popular textbooks for school children, comments, "multicultural approaches enhance, rather than diminish, the quality of historical analysis in the classroom” (Nash 1996: 183). Similarly, Rob Reich attests, "Multicultural education corrects the ethnocentric and chauvinist education so typical of years past, and as such is a truer representation of the history and current composition of the United States” (Reich 2002: 131; see also Susan Wolf's essay in Okin, Cohen, et al. 1999).

One of the aims primarily promoted by educational practitioners had its heyday in the 1980s and early 1990s and since then has slipped from view—namely, using multicultural education to increase the self-esteem of nonmainstream students. ${ }^{6}$ A second aim, however, is alive and well—namely, increasing students' interest in what they are learning by emphasizing 
how it relates to their own lives. (This aim has been a recurring theme of educators over many generations; its most recent instantiation has carried over from the 1960s, when both students and teachers started demanding that the curriculum be "relevant.") This is obviously related to culturally relevant teaching, as mentioned above, but it tends to have a somewhat more limited focus. Culturally relevant teaching incorporates multiple aspects' of students' “cultures,” including learning styles, language patterns, social roles and mores, and so on, in order to help students achieve in the classroom. Educators' concerns with emphasizing the relevance of curriculum to students' own lives tend to center more on content: teachers use students’ knowledge of and interest in rap, for example, to introduce poetic devices such as assonance, internal rhyme, or meter. Multicultural education is seen in this respect as a tool for helping students see themselves and their interests in the curriculum, not as a cudgel to reshape all aspects of curriculum, pedagogy, and practice.

The final aim that multicultural education is sometimes asked to serve is that of enabling students to succeed economically in a multicultural world by teaching them to be comfortable in a diverse workforce and skillful at integrating into a global economy. Thus, New Jersey justified its world languages curriculum by asserting, "To support the growth of New Jersey’s dynamic economy as we move into the twenty-first century, our state needs educated citizens whose multilingual abilities and multicultural sensitivities prepare them to work in a pluralistic society and a global economy. As countries became increasingly interdependent, it is essential that we actively promote proficiency in world languages to improve cross-cultural understanding” (State of New Jersey 1996: Introduction, World Languages; see also State of Delaware 1995:

Geography Standard 3). The multicultural theorist Jim Cummins rather tendentiously makes a similar argument: 
Corporate America wants people ... who can work cooperatively across cultural, linguistic, and racial boundaries to solve problems using this information. It might appear obvious then that our schools should be aiming to produce critical and creative thinkers who are knowledgeable about and sensitive to other cultural perspectives. Any student who emerges into our culturally diverse society speaking only one language and with a monocultural perspective on the world can legitimately be considered educationally ill prepared and perhaps even 'culturally deprived.’” (Cummins 2000: xiv; see also Feinberg 1998: 129-30)

In sum, multicultural education can serve a broad range of possible goals, and has been called on to do so by various constituencies. Because I will be returning to these various goals in subsequent sections of this essay, let me summarize them here: ${ }^{7}$

- Preserve minority group culture

- Foster children's development of autonomy through:

* expanding their "experiential horizons" by exposing them to new options

* posing alternative beliefs, values, ways of life, etc., that spur students to reflect critically on their own lives

- Increase students' exposure to humankind's highest accomplishments

- Promote the civic good by teaching:

* toleration

* mutual respect

* civic cooperation and open-mindedness

* commitment to use of "public reason"

- Promote social justice and equity by:

* Implementing antiracist education

* Teaching students to be attuned to and to fight against social, political, and economic inequality and injustice

* Teaching students in a "culturally congruent" manner 
- Right the historical record

- Foster sense of national unity by demonstrating contributions made by each group

- Increase self-esteem of nonmainstream students

- Increase students' interest in a subject or discipline by emphasizing how it relates to their own lives

- Enable students to succeed economically in an integrated, multicultural workplace and globalized economy

\section{Multicultural Tensions}

These aims may be generally admirable, and well justified each on its own terms as plausible interpretations of “multicultural education," but they are both theoretically and practically incompatible with one another in numerous ways. That's not necessarily an indictment of multicultural education, of course. It could be that some of these characterizations of multicultural education's purposes are misguided, partial, or subordinate to others; once we clear those out of the way, it could be that what's left—multicultural education's overriding goals— are consistent, coherent, and compatible. My purpose in this section and the next, however, is to demonstrate that this isn’t true. First, there are numerous internal inconsistencies between various goals that have considerable claim to being central to any account of what "multicultural education” might mean; and second, there are incompatibilities among goals, practices, and content that are reasonably considered to be central to multicultural education.

Let’s start by considering the first potential aim of multicultural education listed above: preserving minority groups’ cultures. In contrast to many of the other goals, which are clearly promoted by an inclusive curriculum and/or pedagogy that teaches about or responds to a wide variety of groups, preserving a minority culture may require the implementation of an exclusive 
curriculum that teaches the beliefs of the minority group culture instead of the beliefs of other groups. Some religious groups, for example, request this kind of multicultural accommodation in order to prevent their children from encountering (from their perspective) impure, untrue, and/or blasphemous ideas, norms, and practices. These were the grounds given by fundamentalist Christian parents for requesting an alternative reading program for their children in the nowcanonical case Mozert v. Hawkins. To this extent, multicultural education aimed at preserving minority cultures may work in opposition to other goals, such as increasing individual autonomy or promoting mutual respect (by exposing children to a wider variety of alternative views and beliefs). This is not true, however, in all cases; some minority cultures, by contrast, may require a more inclusive curriculum for their preservation, as in Wales, for example, where Welsh language, literature, and culture are taught in addition to English.

Another contrast worth reflecting upon when considering multicultural education's appropriateness for preserving minority groups, especially within the public school, is whether the curricular adjustments are mandatory or optional. Contrary to what one might think, this distinction does not map neatly onto exclusive vs. inclusive curricula. To take the Welsh National Curriculum again, all students living in and attending public schools in Wales are required to take Welsh as a means of attempting to revitalize the language and culture. Thus, this is an example of a mandatory, inclusive multicultural curriculum. In Quebec, on the other hand, all families who are not native Quebecois Anglophones are required to send their children to Francophone schools as a means of preserving and strengthening Francophone Quebecois culture. This constitutes, therefore, a mandatory, exclusive multicultural accommodation. It is possible, as well, to have voluntary, exclusive approaches, whereby families choose to pull their children out of science or reading classes, say, in order to expose them to a minority religious 
perspective exclusively and protect them from encountering different or contradictory

perspectives, as the Mozert parents tried to do. (Whether this can be considered "voluntary" from the child's perspective, however, is questionable, and is an issue that I have addressed in detail elsewhere (Levinson 1999).) Voluntary, inclusive curricula are also possible in the form of electives and after-school programs. Even if one is sympathetic, therefore, to minority groups' claims for public assistance in their cultural preservation, one would need to decide which of these kinds of curricular accommodations are desirable for a public school to provide.

Additional potential conflicts arise when one considers the relationship between minority group preservation, on the one hand, and social justice and equity, on the other. As Susan Moller Okin points out in Is Multiculturalism Bad for Women?, many minority (as well as majority) groups are deeply inegalitarian in their treatment of and mores concerning men and women. When multicultural claims are pressed to explain or (worse) excuse behavior that violates egalitarian norms-Hmong men's kidnapping of young girls excused as culturally acceptable "bride snatching," for example (Okin 1999: 18-19)—social justice and equity are clearly violated. The same may be true for group-respecting forms of multicultural education. To assist groups in preserving their cultures, whether through exclusive or inclusive and voluntary or mandatory means, schools may end up reinforcing these same deep gender (and other) inequalities.

These concerns are not new ones. Philosophers have discussed many of these dilemmas in debating the meaning and justification of multiculturalism itself. But I would argue that they have not been taken as seriously as one might hope by educational theorists, especially the group of “multicultural educationalists” I discussed in section I. For it is not only explicitly grouporiented justifications of multicultural curricula that fall into these dilemmas about inclusion and 
exclusion and the preservation or reinforcement of culturally grounded inequalities. Even multicultural education that is specifically egalitarian and justice-oriented in intent—namely, “culturally congruent” education that is intended to foster especially minority student achievement by incorporating familiar cultural practices, norms, referents, and language into the curriculum, pedagogy, and culture of the school—may end up similarly raising dilemmas about inclusive and exclusive education as well as reinforcing culturally grounded inequities.

To take the equity-oriented concerns first, how does one truly teach both equitably and in a culturally congruent fashion when students come from a culture that values "assertive" or "macho" boys but decries "bossy" or "aggressive” girls? How does a school incorporate cultures that use pimp and pimpin' as positive nouns and verbs for boys or men, but (and?) ho and bitch as derogatory terms for women? What about a culture that values lighter skin over darker skin, or one that describes homosexual behavior as a desecration of God's holy vessel, or one that holds women who are raped responsible for bringing shame upon their family? The educational challenges here are numerous. Of course, the same challenges arise with regard to teaching members of majority cultures; sexism, racism, homophobia, and other inegalitarian expressions of prejudice and discrimination are by no means limited to or necessarily even more predominant in minority groups. But proponents of multicultural education as culturally congruent education frequently seem to ignore the fact that the same inegalitarianism that afflicts majority group cultures also may arise within minority group cultures, and that reinforcing minority students' cultural practices and presuppositions in order to help them achieve may simultaneously reinforce inegalitarian and even racist or sexist norms and behaviors.

I say "frequently" because multicultural educationalists admittedly have acknowledged this problem at times—although they then seem unwilling or unable to confront it head-on. 
Sleeter asks, for instance, "Should empowerment mean teaching these students to recognize and reject sexism, thereby accepting the teacher's definition of the world, or should it mean developing their power to examine the world and act upon it for themselves, which might not involve questioning sexism and could even strengthen it?” (Sleeter 1991: 19). Her answer to this dilemma, however, is to assert that all people’s “perceptions"—-students' and teachers' alike— “embody self-interest and personal experience ... ; nobody’s definition is universal or neutral" (1991: 19-20). Thus, even though she declares elsewhere in the essay that "empowerment and multicultural education are interwoven, and together suggest powerful and far-reaching school reform" in order to achieve "the emancipation of oppressed people" (1991: 2, 22), she is remarkably loathe to take a stand on what that might look like if it means overturning the views of “members of oppressed groups" (1991: 21). This is because the aim of enabling student achievement by teaching in a culturally congruent manner actually shares with the aim of preserving minority group cultures a profound discomfort with making judgments—especially critical judgments—about any culture, especially one that is marginalized or whose members are relatively disempowered. (See Taylor 1992 for an especially insightful critique of the sources and incoherence of this discomfort.)

Furthermore, I would argue that some of the most effective, empowering, and egalitarian culturally congruent teaching of minority students may be found in segregated rather than integrated schools. This takes us back to the exclusivity vs. inclusivity issue raised above. The more culturally diverse a classroom is, the harder it is to teach all students in that classroom in a culturally congruent manner. Culturally congruent education includes adjustments in questioning styles (see Delpit 1995), spoken and written language, choices of texts and other curricular materials, classroom culture, communication with parents and family members, means of 
establishing authority in the classroom, incorporation of students' interests, and more, in response to students' backgrounds, norms, and experiences. All of these play into the "transformation" of education "so that students from racial, cultural, language, and social-class groups will experience equal educational opportunities ... [and] equal status in the culture and life of the school” (Banks 2005: viii). If students' incoming backgrounds, norms, and experiences are fairly homogeneous, then educators can relatively easily adjust their curriculum and practices to capitalize on their students' strengths and meet their students' needs. If the student body is extremely diverse, on the other hand, then this is much harder to achieve. Hence, from the perspective of taking multicultural education to mean culturally congruent teaching, culturally exclusive (segregated) educational settings may actually be more conducive to successful multicultural education than culturally inclusive and integrated settings are.

I think this explains, in fact, some of the ambivalence exhibited by African Americans and others about how much effort should be put into the cause of integrating schools. In a 1998 survey, African-American survey respondents joined white respondents in ranking racial diversity second from the bottom of their preferred characteristics for a good school (Public Agenda Foundation 1998), while black mayors in Seattle, Denver, St. Louis, and Cleveland have attempted to dismantle desegregation practices in their cities (Hochschild and Scovronick 2003: 48-49; see also Massey and Denton 1993). Gloria Ladson-Billings (1994), who champions many of the aims of multicultural education, acknowledges in her classic The Dreamkeepers the appeal of segregated schools, thanks primarily to their greater potential for culturally relevant education. In the same vein, as one African-American veteran teacher explained in an interview in the early 1990s, "we were able to do more with the black students in all-black schools. . . . I got disillusioned with integration because I could not get to my people and tell them all the things 
that they needed to know.” He now enjoys working with the de facto segregated Upward Bound program "because once again, in addition to teaching mathematics, I have the opportunity to get to my people to talk to them and tell them all the important things that I used to preach to black children when I taught in segregated schools. It’s as if I have come back home” (Foster 1997: 6, 7, 11). Vanessa Siddle Walker (1996) documents similar strengths of segregated education in her history Their Highest Potential, and I would argue that evidence from both historical and contemporary freedom schools and from historically black colleges and universities supports this contention, as well (Levinson 2007).

This is not to claim that segregated education is actively desirable all things considered, or even that multicultural education is better achieved under segregated conditions. To the contrary, I remain a firm supporter of integrated schools and I believe that most advocates of multicultural education would be astonished and appalled to be told that multicultural education was best achieved under segregated conditions. This is in part my point. Multicultural education's goals and practices are_-at least with respect to preserving minority groups' cultures or teaching in a culturally congruent manner to achieve social justice, as I have shown, and I would suggest in many other cases, too—at a minimum inconsistent and more likely fundamentally at odds with one another.

\section{Content, Goals, and Practices: A Wobbly Triumvirate}

One of the reasons that advocacy of segregated education seems so much at odds with what we assume multicultural education is about is that embracing diversity would seem to be at the heart of any plausible understanding of the concept. What could multicultural education be about if not learning to accept, understand, and ultimately embrace the rich human diversity that surrounds 
us? This clearly does lie at the heart of many of the goals listed above: antiracism, toleration, respect, expanded horizons, celebration of the contributions made by diverse peoples, and so on. In this section, I want to turn to one of these goals—-that of fostering toleration-in part because it might be thought of as a minimal standard for multicultural education. Clearly, few advocates would be willing to stop at mere toleration as the final goal for multicultural education, but it is hard to imagine any—whether philosophers, multicultural theorists, or educators—who would reject the promotion of toleration as a step on the road to multicultural education. Hence, whereas one might argue that section II focused on overly expansive, exclusive, or demanding conceptions of multicultural education’s goals, here we will focus on a minimal goal: multicultural education should help students become more tolerant of each other. Even under such a minimalist conception of multicultural education's purposes, however, I will argue that it potentially conflicts with diversity-inclusive content. In other words, encouraging toleration may not be best realized through teaching multicultural content—in which case, one has to ask whether multicultural education has any core meaning at all.

There are three forms of tolerance that students can learn.

1. They may learn to tolerate others because "they don't know any better"- this is the basis for many people’s toleration of "white trash," or of the "rednecks" down the road, or of "those Chinese people who eat chicken feet.” This idea is also pithily if idiosyncratically expressed in Georgia’s high school character education curriculum, which specifies that students must learn "Tolerance: the allowable deviation from a standard. Indulgence for beliefs or practices differing from or conflicting with one’s own” (Georgia Department of Education 1997). Although most of us would reject these grounds for teaching toleration, its influence can be insidious (even outside of Georgia!), as the following veteran teacher notes: "I’ve seen white 
teachers let black kids misbehave and then when I ask them why they say, 'I thought that was part of his culture.' ... It's a lack of understanding that what's right and what's wrong is wrong for blacks as well as whites; an unwillingness to take risks and really get involved with black children” (Foster 1997: 61). It’s clear that this is not a productive basis for teaching toleration, both because it can lead to incorrect generalizations about a group (such as that black culture tolerates misbehavior) and because “they don't know any better” cannot set the grounds for respect, which is ultimately needed to promote the civic goods of harmony, cooperation, and equality.

2. A second and more productive ground for toleration is learning to tolerate others because "underneath it all we're all the same"; for example, we are all human beings possessing intrinsic worth and dignity. This is the purpose, I assume, of the following first-grade socialscience standard in California: "Students ... [r]ecognize the ways in which they are all part of the same community, sharing principles, goals, and traditions despite their varied ancestry" (California Department of Education 2000: 1.5.1). When multicultural education is used to teach this form of toleration, it usually takes a comparative turn: students may study kinship structures, religious beliefs and practices, foods, or coming-of-age ceremonies of various groups with an eye to learning to appreciate both the differences and the similarities. The strength of this approach is that once they learn to be tolerant based on a recognition of intrinsic common attributes, students will be inclined to be tolerant of all people, not just those they have specifically met and/or learned about. The weakness of this approach, however, is that it runs the risk of trivializing real differences in order to emphasize our commonality: toleration becomes a lesson on the order of, "They eat tortillas, whereas we eat blintzes, and that group eats mu shu." With the best of intentions, teachers may be inclined to teach, for example, “Allah is just like 
God, only with a different name”-without teaching the ways in which the Islamic, Christian, and Jewish notions of God truly do differ and even conflict. It is extremely easy to give into this temptation, even when one knows better. Soon after the attacks on September 11, 2001, for instance, my student Marvin was researching Islam in order to prepare for an in-class debate about whether we should go to war in Afghanistan. (I was teaching eighth-grade humanities at the time.) “Dr. Levinson, did you know that 'Islam’ means 'peace?’” Marvin asked me excitedly. “Muslims are just like everybody else because we all want peace; that's the basis of their religion!” I readily agreed with him because I was hoping students would develop and/or maintain tolerant attitudes toward Muslims. My approach did nothing, however, to teach him about the real differences between Islam and Christianity (Marvin’s religion), and hence he (and the rest of the class) remained ill-equipped to maintain tolerant attitudes when they learned, for example, about some of the harsher aspects of sharia.

3. This brings us to the third way that students may learn to be tolerant, which is by coming to understand the reasons for a group’s differences. This provides a deeper and more stable basis for toleration (and ultimately potentially for respect), because it helps students learn to engage with real differences in belief and orientation. Unlike with (1) or (2), they learn to understand another person's (or group’s) perspective. For example, a person-let's call her Molly_may be offended the first time she meets an Orthodox Jewish man who refuses to shake her hand, let alone give her a hug hello. But when she learns that he believes that he should not touch a woman who is not his wife, then she becomes tolerant of his behavior because she realizes he's not intentionally being rude. Understanding his reasons doesn’t necessarily lead her to respect his behavior-Molly can understand, and hence be tolerant of, his behavior but still 
think, "He should just get over this"-but it is more likely to ground a respectful relationship than (1) and even possibly than (2).

Multicultural education ideally aims at both (2) and (3) — and hence also aims to replace toleration on the grounds of (1) with toleration on the grounds of (2) and (3). As I mentioned above, we need (2)—-toleration based on appreciation of our common human attributes—because there are only so many different groups, and only so many different behaviors/norms/ ceremonies/etc. of each group, that schools have the time, opportunity, or knowledge to teach about. Hence, it's unreasonable to expect that students (or adults) will tolerate all groups on the grounds of understanding the reasons for their differences; there has to be a more fundamental assumption of toleration based on shared characteristics (common humanity, we all love our children, etc.) that sets the foundation for the hard task of then learning the reasons for differences.

We cannot rely only on (2), however, because, as I noted above, it runs the risk of trivializing real differences; teachers end up teaching or emphasizing superficial differences in order to get at fundamental similarities. This is dangerous since cultural groups do differ fundamentally from each other. Proselytizing door-to-door, taking multiple wives, endorsing sex discrimination, caring for one's child as a stay-at-home father, living according to sharia, eating dogs and rats, calling out responses at the theater or the movies, not believing that Jesus is the son of God, choosing to put one's mother in a nursing home, expecting to live with and be cared for by one's children when one is old, choosing to be a single professional mother —all of these may be experienced by children (and adults) as being fundamentally different from how they lead (and believe it's appropriate to lead) their lives. If a child never learns to be tolerant of fundamental differences as a result of understanding people’s reasons for adopting and endorsing 
these behaviors (i.e., (3)), then she will have a hard time being tolerant of others who really do seem fundamentally different. Of course, which of these are taken to be fundamental differences depends on one's perspective. A few years ago, one of my students asked out of the blue, "Do Chinese people really eat rats?” Since I had just read Peter Hessler’s (2000) account of dining on various species of rat in China, I couldn't in good faith say no, but it was clear that if I said yes, I would confirm his suspicion that Chinese people were at least bizarre, and probably disgusting. Luckily enough, another student, who reveled in her Jamaican background, commented that she loved eating goat curry, even though she knew others found it gross. This (plus the knowledge that the more we talked about food, the more off-track they could get my American history class) inspired other students to reveal what "weird" foods were eaten in their cultures, and to express pride in these differences; as a result, what began as apparently a fundamental difference between "us" and the "Chinese other" became normalized into a superficial difference. ${ }^{8}$

Not all cultural differences can or should be normalized, however, and not all can necessarily be handled even by (3), teaching others the reasons behind these differences. Returning to the example of the Orthodox Jew above, it is relatively easy for Molly to learn to tolerate his not shaking her hand because once she knows the reason, she can interpret it as one way his culture expresses fidelity, which is a value Molly shares. In this respect, Molly ultimately tolerates his behavior because she sees it arising out of a shared value-because in this respect at least, underneath it all they're the same: they both believe in the value of fidelity. If Molly discovers, however, that fidelity is expressed in this way (not touching other women) because women are viewed as temptresses, and hence as in some way unclean, then her newfound understanding of his behavior confronts her with a fundamental difference. She doesn't interpret the gendered world the same way at all, so what Molly at first might have seen 
as rude (“why won’t he shake my hand?”), and then at second glance seen as a somewhat oldfashioned but charming way of demonstrating fidelity to his wife ("oh, he'll touch only her, how sweet”), now at third glance she sees as a slap in the face to herself and half the world's population (“he won’t shake my hand because I'm inherently unclean?!). The true test of Molly's toleration of difference is her remaining tolerant even now—now, note, that she's learned more about his beliefs, rather than less.

As this example reveals, learning about others does not necessarily guarantee that we will become more tolerant of their behavior or beliefs, let alone more respectful of them. The more we learn, the more different and the less deserving of toleration someone, or some group, may seem. In this respect, multicultural education understood as multicultural content is both a tool and a potential hindrance to promoting mutual toleration and respect. Does this mean that multicultural education is the wrong tool to use in achieving the aims of promoting toleration and respect? I don’t think so. But its implementation is much more complex than is usually acknowledged.

We just saw how multicultural content may be a useful approach to achieving an important goal of multicultural education (in this case, promoting toleration), but that it is more complex than is usually assumed. I want now to turn to another example in which neither the content nor practices of multicultural education (such as culturally congruent teaching) seem to be evident—where they are in fact consciously rejected, to a certain extent—but which may achieve some of the central goals of multicultural education more consistently than almost any self-consciously multicultural school. I am thinking here of the network of more than 50 KIPP charter schools that has expanded across the United States over the past five or so years. Students who attend a KIPP school participate in an extended school day that keeps them away from 
home, and often from their neighborhoods as well, from early in the morning until late in the afternoon. They follow similar rigorous academic curricula that leave relatively little room for individual teacher discretion in comparison to some other schools. Students attending KIPP schools are overwhelmingly black and/or Hispanic, and the vast majority are poor; to this extent, KIPP schools are often less diverse than other schools in the district. As soon as students enter a KIPP school, they are taught to "SLANT": Sit up straight, Listen, Ask and answer questions, Nod their head if they understand, and Track the speaker. KIPP elementary and middle schools usually attempt to prepare students for and place them in exclusive private/independent schools, as well as in select public schools (often ones that require an exam or place other barriers to entry). Almost all of these target schools have a student body that is predominantly white and middle class. Although reliable data are only just becoming available, it appears that KIPP students do much better on standardized measures of academic performance and go onto college at significantly higher rates than comparable students who attend non-KIPP schools in the same district (KIPP 2007; KIPP Academy Lynn Charter School 2003).

It is arguable that KIPP schools help students achieve more of the goals of multicultural education—including helping students develop autonomy (especially by expanding their universe of options), become more empowered citizens, and achieve economic competitiveness, as well as promoting equity and social justice by helping thousands of poor, minority students gain admission to and succeed in highly selective secondary schools and colleges-than do most other schools in the country. They do so, however, by explicitly teaching students what and how they need to know, do, and behave to succeed in the majoritarian culture of these selective schools—in other words, arguably, how to fit into the culture of the white, middle-class, educated elite. (See Hochschild and Scovronick 2003: chap.7 for a related argument.) Some 
multicultural education theorists thus reject approaches like KIPP's (Sleeter 1991). But this rejection strikes me as being reflexive rather than thoughtful. James and Cherry Banks define multicultural education as "a field of study designed to increase educational equity for all students that incorporates, for this purpose, content, concepts, principles, theories, and paradigms from history, the social and behavioral sciences, and particularly from ethnic studies and women’s studies” (Banks and Banks 2004: xii). If schools such as KIPP “increase equity for all students” without incorporating content, principles, or paradigms based in ethnic and women’s studies — and, let's pretend for the sake of argument, in fact increase equity far better than most schools that do incorporate ethnic and women's studies content and paradigms — then does the fault lie with schools like KIPP, or with the operative conception of multicultural education?

\section{Conclusion}

Multicultural education is a powerful idea. It has rallied many to take up the causes of improving the education of students who have suffered far too long in uncaring and ineffective schools, combating racism, giving appropriate recognition to the many groups and peoples who helped build and shape our national history and culture, and limiting majoritarian impulses to quash minority ways of life. As such, multicultural education deserves to be celebrated. But it is also an empty idea, at least taken solely on its own terms. It embraces so many laudable goals, practices, and types of content that they frequently contradict each other both in theory and in practice. Proponents of one vision of multicultural education chastise proponents of other visions for getting multicultural education wrong-but all conceptions of multicultural education, whether minimalist, maximalist, or in between, introduce complexities, complications, and potential contradictions of their own. Multicultural education is probably best thought of as an 
abbreviation or stand-in for other values that we hold regarding the aims, practices, and content of education. This approach sometimes can work, and may even be effective at rallying people who would normally be at odds with one another to work together in service of a shared (or apparently shared) goal. But its practical use as an umbrella term that fosters warm and fuzzy feelings of unity (at least among certain groups) shouldn’t be confused with its theoretical coherence, of which there is little to none. When we see references to "multicultural education," therefore, we must always ask what is actually meant, and realize that the term may obscure as much as it enlightens. ${ }^{9}$ 
Notes

1. Although Kymlicka (1995: 59-60) does notably support voluntary segregated schools for Native Americans and native Hawaiians.

2. Although multiculturalism and antiracism are frequently mentioned in the same breath, Larry Blum (1999) points out that they have rather different value bases.

3. It should be noted that not all philosophers limit their multicultural critique to curricula alone. With reference to protecting minority groups' rights and cultures, Kymlicka explains, for example, we must "examine the structure of institutions (e.g., the language, calendar, and uniforms that they use) and the content of schooling and media, since all of these take the majority culture as the 'norm'” (Kymlicka 1999: 33).

4. It's worth noting that I've given no examples of this aim in U.S. state standards, as it would be politically suicidal for a state board or department of education to say that a goal of the curriculum is to "reconstruct society" or to empower teachers as "agents of social change." Even explicit discussion of racism as an ongoing, present challenge as opposed to something of merely historical interest is unusual in state curriculum frameworks in the United States, although other countries make the link much more readily (see, e.g., the U.K.'s Qualifications and Curriculum Authority 2007a).

5. It should be noted that political theorists interested in multiculturalism have also written a tremendous amount about the empowerment of minority or marginalized cultural groups, but this work tends not to be linked to writing on multicultural education.

6. Self-esteem has been decoupled from multicultural education both because the concept itself became an object of public derision thanks to its overuse and misuse in the 1990s (Owens and Stryker 2001) and because psychologists’ research on self-esteem has demonstrated conclusively that self-esteem is an extremely complex construct that has little to do with, say, hearing positive things about their "group” or "I am special” mantras (Covington 2001).

7. These aims could obviously be broken up and recombined in a variety of ways.

8. I should note that these examples provide support for my contention at the end of section II that diverse, integrated schools may have tremendous value, including in promoting some goals of multicultural education. These discussions, and efforts to promote tolerance and mutual respect, are far easier in an integrated setting where children can become friends with each other and experience commonality (worries over test, love of basketball, dislike of a teacher, treating others nicely) in a natural setting and then confront some of their differences. With a shared basis of experience, and an experience of common humanity already, it's an easier and safer basis on which to respect difference. (See Pettigrew and Tropp 2000 for a comprehensive meta-analysis of research supporting this conclusion.) In a segregated setting, on the other hand, there is a greater sense of "otherness" about the groups one is being taught about.

9. I have discussed my ideas about multicultural education with numerous people, many of whom have also generously commented on various drafts I've written about the topic. I am grateful to the following people for having helped me clarify my thoughts about multicultural education, although I hasten to add that none read (nor, hence, bear any responsibility for) this exact chapter: Rob Reich, Mica Pollock, Prudence Carter, Liz Canner, Larry Blum, Robert Fullinwider, Jennifer Hochschild, Michael Marder, Cynthia Levinson, Sanford Levinson, Marc Lipsitch, Michael Merry, Eamonn Callan, Walter Feinberg, Denis Philips, Howard Gardner, Chris Higgins, Sarah Tsang, Jack Dougherty, Jasmine Mahmoud, Lindy Hess, James Foreman, Pam Gordon, and participants in seminars, workshops, or other presentations I gave at Harvard, 
Cornell, Teachers College, Stanford-Illinois Philosophy of Education Summer Institute, University of Texas at Austin, and Radcliffe Institute for Advanced Study. I am also grateful for the financial and intellectual resources provided by Spencer Foundation/National Academy of Education and Radcliffe Institute for Advanced Study 


\section{References}

Appiah, K. A. (1996). “Culture, Subculture, Multiculturalism: Educational Options.” In Public Education in a Multicultural Society, ed. R. K. Fullinwider (pp. 65-89). Cambridge: Cambridge University Press.

Banks, J. A. (2001a). “Approaches to Multicultural Curriculum Reform.” In Multicultural Education: Issues and Perspectives, 4th ed., ed. J. A. Banks and C. A. M. Banks (pp. 225-46). New York: Wiley.

—. (2001b). "Multicultural Education: Characteristics and Goals.” In Multicultural Education: Issues and Perspectives, 4th ed., ed. J. A. Banks and C. A. M. Banks (pp. 330). New York: Wiley.

—. (2001c). Preface. Multicultural Education: Issues and Perspectives, 4th ed., ed. J. A. Banks and C. A. M. Banks (pp. 1-2). New York: Wiley.

—. (2005). Series Introduction. In Un-Standardizing Churriculum: Multicultural Teaching in the Standard-Based Classroom, by C. E. Sleeter (p. viii). New York: Teachers College Press.

Banks, J. A., and C. A. M. Banks. (2004). Handbook of Research on Multicultural Education. San Francisco: Jossey-Bass.

Blum, L. (1999). “Value Underpinnings of Antiracist and Multicultural Education.” In Systems of Education: Theories, Policies and Implicit Values (Education, Culture, and Values, Vol. 1, ed. M. Leicester, C. Modgil, and S. Modgil (pp. 3-14). London: Falmer Press. California Department of Education. (2000). History-Social Science Content Standards for California Public Schools, Kindergarten Through Grade Twelve. 
Covington, M. V. (2001). “The Science and Politics of Self-Esteem: Schools Caught in the Middle.” In Extending Self-Esteem Theory and Research: Sociological and Psychological

Currents, ed. T. J. Owens, S. Stryker, and N. Goodman (pp. 351-74).

Cambridge:Cambridge University Press.

Cummins, J. (2000). Foreword. In Affirming Diversity, by S. Nieto (pp. xiv-xvi). New York: Longman.

Delpit, L. (1995). Other People's Children. New York: The New Press.

Feinberg, W. (1998). Common Schools/ Uncommon Identities. New Haven: Yale University Press.

Foster, M. (1997). Black Teachers on Teaching. New York: The New Press.

Gay, G. (1995). “Curriculum Theory and Multicultural Education.” In Handbook of Research on Multicultural Education, ed. J. A. Banks and C. A. M. Banks (pp. 25-41). New York: Simon \& Schuster Macmillan.

—. (2000). Culturally Responsive Teaching: Theory, Research, and Practice. New York: Teachers College Press.

— (2001). "Educational Equality for Students of Color.” In Multicultural Education: Issues and Perspectives, 4th ed., ed. J. A. Banks and C. A. M. Banks (pp. 197-224). New York: Wiley.

Georgia Department of Education. (1997).“Values and Character Education Implementation Guide.” Retrieved February 17, 2009, from http://chiron.valdosta.edu/whuitt/col/affsys/valuesga.html.

Grant, C. A., and C. E. Sleeter. (1999). Making Choices for Multicultural Education: Five Approaches to Race, Class, and Gender, 3rd ed.. New York: Wiley. 
_ (2001). "Race, Class, Gender, and Disability in the Classroom.” In Multicultural Education: Issues and Perspectives, 4th ed., ed. J. A. Banks and C. A. M. Banks (pp. 5981). New York: Wiley.

Gutmann, A. (1996). “Challenges of Multiculturalism in Democratic Education.” In Public Education in a Multicultural Society, ed. R. K. Fullinwider (pp. 156-79). Cambridge: Cambridge University Press.

Hessler, P. (2000). “A Rat in My Soup.” The New Yorker, July 24, pp. 38-41.

Hochschild, J., and N. Scovronick. (2003). The American Dream and the Public Schools. New York: Oxford University Press.

KIPP. (2007). "KIPP: Knowledge is Power Program." Retrieved October 12, 2007, from www.kipp.org.

KIPP Academy Lynn Charter School. (2003). "KIPP Academy Lynn Charter School Final Application." November 14, 2003. Retrieved October 11, 2007, from http://www.doe.mass.edu/charter/approved/0429.pdf.

Kymlicka, W. (1995). Multicultural Citizenship. Oxford: Oxford University Press.

— (1999). "Liberal Complacencies.” In Is Multiculturalism Bad for Women? ed. J. Cohen, M. Howard, and M. C. Nussbaum (pp. 31-34). Princeton: Princeton University Press. Ladson-Billings, G. (1994). The Dreamkeepers: Successful Teachers of African American Children. San Francisco: Jossey-Bass.

Levinson, M. (1999). The Demands of Liberal Education. Oxford: Oxford University Press. — (2007). Hearing Voices, Telling Stories: Communal Constructions of Civic Identity. Unpublished manuscript. 
Macedo, S. (2000). Diversity and Distrust: Civic Education in a Multicultural Democracy. Cambridge, MA: Harvard University Press.

Massey, D. S., and N. A. Denton. (1993). American Apartheid: Segregation and the Making of the Underclass. Cambridge, MA: Harvard University Press.

Montana Office of Public Instruction. (1999). Montana Standards for Literature. URL: http://www.opi.mt.gov/pdf/standards/ContStds-Literature.pdf. Accessed October 15, 2007. Published by the Montana Office of Public Instruction.

Moody v. Cronin. F. Supp., C.D. Ill. 484: 270 (1979).

Nash, G. (1996). "Multiculturalism and History: Historical Perspectives and Present Prospects.” In Public Education in a Multicultural Society: Policy, Theory, Critique, ed. R. K. Fullinwider (pp. 183-202). Cambridge: Cambridge University Press.

New York State. (1996). Learning Standards for Languages Other than English, New York State Education Department. New York State Education Department. URL: http://www.emsc.nysed.gov/ciai/lote/pub/lotelea.pdf. Accessed October 15, 2007.

_ـ (2003). New York State Learning Standards: English Language Arts. New York State Education Department. URL: http://www.emsc.nysed.gov/ciai/ela/elals.html. Accessed: March 7, 2003

Nieto, S. (2000). Affirming Diversity: The Sociopolitical Context of Multicultural Education, $3^{\text {rd }}$. ed. New York: Longman.

__ (2001). "School Reform and Student Learning: A Multicultural Perspective.” In Multicultural Education: Issues and Perspectives, 4th ed., ed. J. A. Banks and C. A. M. Banks (pp. 381-401). New York: Wiley. 
NSW Department of Education and Training and Office of the Board of Studies NSW. (2007).

"Making Multicultural Australia." Retrieved October 16, 2007, from http://www.multiculturalaustralia.edu.au/purpose/index.php.

Okin, S. M., J. Cohen, et al. (1999). Is Multiculturalism Bad for Women? Princeton:: Princeton University Press.

Owens, T. J., and S. Stryker (2001). “The Future of Self-Esteem: An Introduction.” In Extending Self-Esteem Theory and Research: Sociological and Psychological Currents ed. T. J. Owens, S. Stryker, and N. Goodman (pp. 1-9). Cambridge: Cambridge University Press. Pettigrew, T. F., and L. R. Tropp. (2000). “Does Intergroup Contact Reduce Prejudice? Recent Meta-Analytic Findings.” In Reducing Prejudice and Discrimination. Claremont Symposium on Applied Social Psychology and S. Oskamp. Mahwah, NJ: Erlbaum.

Farkas, S. and J. Johnson. (1998). Time to Move On: African American and White Parents Set an Agenda for Public Schools. New York: Public Agenda. Retrieved February 17, 2009, from http://www.publicagenda.org/files/pdf/time_to_move_on.pdf.

Qualifications and Curriculum Authority. (2007a). "Respect for All." Retrieved October 17, 2007, from http://www.qca.org.uk/qca_6753.aspx.

Qualifications and Curriculum Authority. (2007b). "Respect for All Ethos." Retrieved October 22, 2007, from http://www.qca.org.uk/qca_6756.aspx.

Rawls, J. (1993). Political Liberalism. New York: Columbia University Press.

Reich, R. (2002). Bridging Liberalism and Multiculturalism in American Education. Chicago: University of Chicago Press.

Siddle Walker, V. (1996). Their Highest Potential: An African American School Community in the Segregated South. Chapel Hill: University of North Carolina Press. 
Sleeter, C. E. (1991). “Introduction: Multicultural Education and Empowerment.” In Empowerment through Multicultural Education, by C. E. Sleeter (pp. 1-23). Albany: State University of New York Press.

—. (2005). Un-Standardizing Curriculum: Multicultural Teaching in the Standards-Based Classroom. New York: Teachers College Press.

State of Delaware. (1995). Content Standards. Social Studies Framework. Delaware Department of Education. http://www.doe.k12.de.us/infosuites/staff/ci/content_areas/socialstudies.shtml Retrieved February 16, 2009.

State of New Jersey. (1996). "New Jersey World Languages Curriculum Framework.” New Jersey Core Curriculum Content Standards. Retrieved February 17, 2009, from http://www.nj.gov/education/frameworks/worldlanguages/.

Tamir, Y. (2002). "Education and the Politics of Identity.” In A Companion to Philosophy of Education, ed. R. Curren (pp. 501-508). Oxford: Blackwell.

Taylor, C. (1992). Multiculturalism and "The Politics of Recognition." Princeton: Princeton University Press.

Wisconsin v. Yoder. U.S., Supreme Court. 406: 205 (1972).

Young, I. M. (1990). Justice and the Politics of Difference. Princeton: Princeton University Press.

Moody v. Cronin. F. Supp., C.D. Ill. 484: 270 (1979).

Nash, G. (1996). "Multiculturalism and History: Historical Perspectives and Present Prospects.” In Public Education in a Multicultural Society: Policy, Theory, Critique, ed. R. K. Fullinwider (pp. 183-202). Cambridge: Cambridge University Press. 
New York State. (1996). Learning Standards for Languages Other than English, New York State Education Department. New York State Education Department. URL: http://www.emsc.nysed.gov/ciai/lote/pub/lotelea.pdf. Accessed October 15, 2007. — . (2003). New York State Learning Standards: English Language Arts. New York State Education Department. URL: http://www.emsc.nysed.gov/ciai/ela/elals.html. Accessed: March 7, 2003.

Nieto, S. (2000). Affirming Diversity: The Sociopolitical Context of Multicultural Education, $3^{\text {rd }}$. ed. New York: Longman.

—_. (2001). "School Reform and Student Learning: A Multicultural Perspective.” In Multicultural Education: Issues and Perspectives, 4th ed., ed. J. A. Banks and C. A. M. Banks (pp. 381-401). New York: Wiley.

NSW Department of Education and Training and Office of the Board of Studies NSW. (2007). "Making Multicultural Australia." Retrieved October 16, 2007, from http://www.multiculturalaustralia.edu.au/purpose/index.php.

Okin, S. M., J. Cohen, et al. (1999). Is Multiculturalism Bad for Women? Princeton:: Princeton University Press.

Owens, T. J., and S. Stryker (2001). “The Future of Self-Esteem: An Introduction.” In Extending Self-Esteem Theory and Research: Sociological and Psychological Currents ed. T. J. Owens, S. Stryker, and N. Goodman (pp. 1-9). Cambridge: Cambridge University Press. Pettigrew, T. F., and L. R. Tropp. (2000). “Does Intergroup Contact Reduce Prejudice? Recent Meta-Analytic Findings.” In Reducing Prejudice and Discrimination. Claremont Symposium on Applied Social Psychology and S. Oskamp. Mahwah, NJ: Erlbaum. 
Farkas, S. and J. Johnson. (1998). Time to Move On: African American and White Parents Set an Agenda for Public Schools. New York: Public Agenda. Retrieved February 17, 2009, from http://www.publicagenda.org/files/pdf/time_to_move_on.pdf.

Qualifications and Curriculum Authority. (2007a). "Respect for All." Retrieved October 17, 2007, from http://www.qca.org.uk/qca_6753.aspx.

Qualifications and Curriculum Authority. (2007b). "Respect for All Ethos." Retrieved October 22, 2007, from http://www.qca.org.uk/qca_6756.aspx.

Rawls, J. (1993). Political Liberalism. New York: Columbia University Press.

Reich, R. (2002). Bridging Liberalism and Multiculturalism in American Education. Chicago: University of Chicago Press.

Siddle Walker, V. (1996). Their Highest Potential: An African American School Community in the Segregated South. Chapel Hill: University of North Carolina Press.

Sleeter, C. E. (1991). “Introduction: Multicultural Education and Empowerment.” In Empowerment through Multicultural Education, by C. E. Sleeter (pp. 1-23). Albany: State University of New York Press.

—. (2005). Un-Standardizing Curriculum: Multicultural Teaching in the Standards-Based Classroom. New York: Teachers College Press.

State of Delaware. (1995). Content Standards. Social Studies Framework. Delaware Department of Education. http://www.doe.k12.de.us/infosuites/staff/ci/content_areas/socialstudies.shtml Retrieved February 16, 2009. 
State of New Jersey. (1996). "New Jersey World Languages Curriculum Framework.” New Jersey Core Curriculum Content Standards. Retrieved February 17, 2009, from http://www.nj.gov/education/frameworks/worldlanguages/.

Tamir, Y. (2002). "Education and the Politics of Identity.” In A Companion to Philosophy of Education, ed. R. Curren (pp. 501-508). Oxford: Blackwell.

Taylor, C. (1992). Multiculturalism and "The Politics of Recognition." Princeton: Princeton University Press.

Wisconsin v. Yoder. U.S., Supreme Court. 406: 205 (1972).

Young, I. M. (1990). Justice and the Politics of Difference. Princeton: Princeton University Press. $</ \mathbf{R}>$ 